\title{
Research
}

\section{Influence Of Organizational Culture, Work Discipline, And Work Environment On Employee Performance}

\author{
Bagas Pradana Aulia'; Imam Sucipto²; Ahmad Gunawan ${ }^{3}$ \\ ${ }^{123}$ Management Study Program, Pelita Bangsa University \\ 1'bagaspradanaaulia1@gmail.com, ${ }^{2}$ imamsucipto64@yahoo.com, ${ }^{3}$ ahmadgunawan@pelitabangsa.ac.id \\ * Corresponding author
}

Received: October 14, 2021 Accepted: November 25, 2021 Published: December 31, 2021

To cite this article: Aulia,B.P.,Sucipto,I. \& Gunawan, A.(2021). Influence of organizational culture, work discipline, and work environment on employee performance. The Management Journal Of Binaniaga, 6 (2), 191-206. doi: $10.33062 / \mathrm{mib} . v 6 \mathrm{i} 2.464$

Abstract. The purpose of this study is to ascertain the effect of organizational culture, work discipline, and work environment on employee performance at PT Mitsubishi Logistics Indonesia's repack division. The population is comprised of employees of PT Mitsubishi Logistics Indonesia, and the sample size was 74. The sampling technique used in this study is Non-Probability Sampling with a saturated sampling type. Multiple linear regression analysis is used to analyze data using the SPSS software version 25. According to the study's results, corporate culture, work discipline, and work environment positively and substantially influence employee performance concurrently. Then, organizational culture influences employee performance, followed by work discipline and the work environment.

Keywords: Organizational culture, work discipline, work environment, employee performance

\section{INTRODUCTION}

\section{Background}

A firm must make the best use of its resources, one of which is human resources. It can compete with other firms in a company with substantial human resources. Human resources are the key drivers of the wheels of the firm. Without human resources, a firm will be hard to reach its objectives, thus managing human resources is vital. The achievement of corporate goals, employee happiness, and community satisfaction will be achieved if personnel management can process the workforce in this way (Hasibuan, 2017: 10).

Each firm indeed has difficulties that might impact employees' excellent performance. The difficulty develops due to the lack of business norms and functions.

In increasingly intense enterprise rivalry, the performance of employees is undoubtedly essential. Any firm surely wants its personnel to perform highly to Attain the main objective of profit and continue in business rivalry. Excellent and consistent staff performance will influence the organization positively.

Furthermore, vice versa, low staff performance would hamper the attainment of business objectives. Of course, if this occurs, the firm will assess poor employee performance, skill level, and inventiveness in the performance of its tasks so that its goals remain to be accomplished. Corporate performance is excellent if employee performance (individual performance) is good (Sulaksono, 2015: 106).

Each enterprise must endure an employee performance decline that is common in each firm. Signs of a fall in employee performance include hard-to-come production goals, bad working attitudes and characteristics, poor work discipline when seen through employee absenteeism, and a less supportive working environment. Each firm can address these signs. Individual characteristics, work efforts, and organizational support can be a

Bagas Pradana Aulia; Imam Sucipto; Ahmad Gunawan. Influence of organizational culture, work discipline, and work environment on employee performance. 
way to overcome the effects of a company's decreasing performance (Simamora in Sulaksono, 2015: 107).

Organizational culture includes factors that impact employee performance. Employees at firms with a solid organizational culture are more involved than employees in companies with a weak corporate culture (Robbins in wardani journal et al., 2016). In addition to the corporate culture, work discipline also influences employee performance. Work performance may be accomplished when people are disciplined. Without excellent employee discipline, a business cannot reach its targets (Hasibuan, 2017: 193). Then the performance of staff is impacted by the working environment and organizational culture, and work discipline. The less comfortable working conditions might drain and take longer and do not assist in creating an effective working system so that the firm's objectives are impeded (Sedarmayanti, 2018: 28).

PT Mitsubishi Logistics is a subsidiary of the Japanese Mitsubishi Corporation. The firm is involved in warehousing to store and repackage food goods, drinks, medical equipment, and other enterprises. The problem with this firm is the reduction in employee performance because the amount produced does not meet the company's objective.

In Table 1 of the production results, indications of decreasing employee performance are shown that do not meet the objectives laid out by the firm.

Table 1 Achievement of Production Results November 2020 - March 2021

\begin{tabular}{|l|l|l|l|}
\hline Month & Production Target (in cardboard) & $\begin{array}{l}\text { Achievement } \\
\text { of Production } \\
\text { (in cardboard) }\end{array}$ & Percentage \\
\hline November & 24.000 & 17.247 & $71,86 \%$ \\
\hline December & 23.000 & 18.917 & $82,24 \%$ \\
\hline January & 25.000 & 20.477 & $81,9 \%$ \\
\hline February & 23.000 & 19.265 & $83,76 \%$ \\
\hline March & 26.000 & 21.149 & $81,34 \%$ \\
\hline
\end{tabular}

Source: Production Section of PT Mitsubishi Logistics Indonesia, 2021.

A production target of 1,000 cartons per day was specified in the table. There were 24 working days in November with a production target of 24,000 cartons. The production achievement reached 17,247 cartons with the target percentage of $71.86 \%$, followed by a December increase of $82.24 \%$, a January decrease of $81.9 \%$, then revisits in February with the figure of $83.76 \%$. Table 1.1 shows that the production objective never exceeds the company's specified aim.

To keep this research narrow, the authors confined the difficulties of the study solely to the effects on staff performance in the repackaging department of PT Mitsubishi Logistics in Indonesia from the organizational culture, work discipline, and work environment. Researchers want to perform this study with the title "Influence of Organizational Culture, Work Discipline and Work Environment in PT Mitsubishi Logistics Indonesia's Repack Section." The author is interested in this study about difficulties that the author and colleagues who operate in the firm regularly experience.

\section{REVIEW LITERATURE}

\section{Employee Performance}

According to Mangkunegara (2017:67), the quality and amount of work performed by an employee in performance in line with those given by the firm are accomplished. Sulaksono (2015: 95) then defines the performance of employees as both the quality and the quantity accomplished by personnel per unit time to carry out their job activities in line with their assignments. The definition provided by Simamora (in Beiferly et al., 2021) of performance is defined as the degree of work or work obtained by workers under a specific unit of time according to the regulations set by the firm. Finally, a definition not so different from the performance of Hariandja (in the newspaper Sucipto and Gunawan in 2021) is the

Bagas Pradana Aulia; Imam Sucipto; Ahmad Gunawan. Influence of organizational culture, work discipline, and work environment on employee performance. 
outcome of work done via workers or specific acts displayed according to their tasks inside the firm.

Sedarmayanti explains that the performance of employees may also be impacted by various elements (Sulaksono, 2015: 107), namely: 1. Attitude of mind; 2. Education; 3. Skills; 4. Leadership; 5. Revenue level; 6. Discipline; 7. Communication

Robbins (Sulaksono, 2015: 124) indicates in addition to the employee performance factors: In addition to:

1. Quality: Job quality may be assessed based on the employee's perception of the quality of the production work and the perfection of tasks into the talents and abilities of the workers.

2. Quantity: The quantity generated is stated in the number of units and the number of completed business cycles.

3. Punctuality: The activity level finished at the start of the specified time is considered from the point of coordination with results and maximizes the time available for other activities.

4. Effectiveness: The degree of the utilization (energy, money, technology, raw materials) of organizational resources is maximized to improve the return on resources for each unit.

5. Independence: is an employee's level that will perform his job later

6. Work engagement: is a location where workers work with the agency and work in-office responsibilities.

\section{Culture Organizational}

According to Setyaningrum et al. (2019: 61), that organization's culture is defined as a belief, attitude, and value usually present in the organization, more simply expressing the culture in which members of the organization conduct things inside an organization. According to Robbins (2015: 2 in Sulaksono), the organizational culture can then be seen as an illustration of the standard basic norms that members in a group study as a means of resolving external and internal factors, and then new members can learn how to prepare and feel about the Sutrisno problem (Muis et al., 2018):

The organizational culture, as stated by Sathe (in Sulaksono, 2015: 11), can then also be influenced by several factors:

1. Share: is an organization's uniform, for instance, Korpri clothes for civil servants (PNS), batik Persatuan Guru Republik Indonesia (PGRI), and workers in every firm they operate.

2. Sharesaying: are particular words like slogans or phrases. There is, for example, the term Tut Wuri Handayani in the culture of educational organizations. The phrase $5 \mathrm{R}$ typically implies succinct, clean, relaxed, caring, and diligent corporate sector.

3. Sharedoing is a routine organization action. For instance, in Sulawesi mapalus, in Bali nguopin. Routine activities are also typical in some organizations, for example, stretching exercises before work.

4. Share feelings: Words that communicate somebody's happiness and sorrow. For example, sympathies to catastrophe victims, congrats on someone's achievement. Sulaksono (2015: 15) explained that there are six organizational culture markers, namely:

a. Innovative: This means that each employee pays delicate attention to any problems that the entire organization may be at risk of loss.

b. Focus on the problem: In detail, the thoroughness and the precision of the employee in the performance of his duties will be described.

Bagas Pradana Aulia; Imam Sucipto; Ahmad Gunawan. Influence of organizational culture, work discipline, and work environment on employee performance. 
c. Results-oriented: the supervision and empowerment of a boss over his subordinates. The aims of the organization and its groups and members can be specified using this oversight.

d. Oriented towards the interests of the employees: teamwork, where collaboration may be established if the manager can effectively oversee his subordinates, determines the success or performance.

e. Aggressive at work: High productivity is achieved if the performance of employees fulfills the criteria required to accomplish their jobs.

f. Stability of work: employees must remain in a position to maintain their health state. Thus requirements such as these can be satisfied if nutritious meals are consumed frequently based on the nutritionists' recommendations.

\section{Discipline of work}

According to Hasibuan (193:2017), the discipline of work is an employee's awareness and willingness to comply with all written and unwritten regulations in the organization. While Keith Davis (in Mangkunegara, 129:2017) claims it is possible to view work discipline as a collection of corporate norms to reinforce managerial execution. Siagian then described the discipline of the job as a management activity (Sucipto and Gunawan, 2021) to implement the company's organization.

Hasibuan (2017: 194) describes various work discipline indicators, namely:

1. Goals and abilities: The objectives must be clearly, ideally defined, and sufficiently challenging for the employee's ability. Indicates that the goals (works) charged to the employee must be in line with the employee's ability to work with great enthusiasm and discipline.

2. Example of the leader: his subordinates use the leader as a role model and role model. Leaders need to provide a good example, be honest, fair, and do the word. The discipline of subordinates will be good with the example of a competent leader. If the leader's example is not excellent (without discipline), the subjects will lack discipline.

3. Response: Response will provide the company's personnel with happiness and passion for their work. The larger the return of services, the better the employee's discipline. Conversely, when the return of employee discipline in tiny services becomes modest.

4. Justice: Justice utilized in providing a reward (recognition) or punishment as the foundation of knowledge would encourage excellent employee discipline.

5. Waskat: means that the superior must actively and personally supervise his subordinates' behavior, moral behavior, attitudes, passions at work, and performance. Waskat successfully encourages employees' discipline and morality. Employees feel that their superiors give them attention, guidance, guidance, guidance, and supervision.

6. Punitive sanctions: the degree of disciplinary penalties to be enforced also affects employees' good or bad discipline. Punitive penalties should be laid down for all workers based on rational, reasonable, and adequately informed considerations.

7. Firmness: the boss must be bold and firm in punishing any indisciplined employee by the imposed punishments. Leaders who dare to act forcefully will be punished and acknowledged by subordinates for workers who are not disciplinary.

Bagas Pradana Aulia; Imam Sucipto; Ahmad Gunawan. Influence of organizational culture, work discipline, and work environment on employee performance. 
8. Human relationships: vertical and horizontal relationships consisting of a single, direct, group, and cross-relationship should be harmonious. The establishment of a healthy human interaction will create an atmosphere and a comfortable working environment. It is motivated, good corporate discipline. It will generate employee discipline if the organization's humanitarian relationship is good.

\section{Environment of work}

According to Sedarmayanti (Primananda and Djastuti, 2015), the workplace is the complete infrastructure and materials present, as an employee and as a group. In Sofyandi's perspective, Dermawan (in the Mamesah et al. journal 2016) claimed that the working environment was a physical or non-physical environment of the work of the employee, which may offer a comfortable impression, a sense of safety, calmness, and a sensation of being at home to work. Sutrisno (Sucipto and Gunawan magazines) found that the working environment might be integral to the existing employee infrastructure. Then there are 11 indicators of the working environment in Sedarmayanti (2018: 28), namely:

1. Light: illumination or lighting is highly useful for safety and easy working for the personnel. Light may essentially be split into two elements, namely sunshine and artificial light in the form of lights. Therefore, a bright but not dazzling illumination must be noted. With excellent illumination, staff may work wholly and deliberately to achieve a suitable quality of their job. Less clear light (less adequate light) leads to a less clear vision, making work slower, numerous mistakes, and eventually less efficient in doing the task so that the company's goals are difficult to reach.

2. Temperature: people have varying body temperatures under standard settings. Working in overly hot or cold conditions might result in lower performance. In general, the usage of higher physical effort increases with hot and wet circumstances, such that employees feel very fatigued and their performance decreases.

3. Humidity: the amount of water in the air, generally in percentages, is the moisture. This humidity is connected or influenced by the air temperature and the movement of air and heat from the air, combined, affects the person's condition when heat is received or released from the body.

4. Circulation of air: The surrounding air is unclean if the air's oxygen levels are lowered and combined with gasses or smell that damage the body's health. Dirty air might feel breathless and should not linger too long because it will impact the health of the body and speed up the tiredness process.

5. Noise: Sound not wanted by the ear is noise. Unwanted, since the sound might interfere with tranquillity, hearing loss, and communication mistakes in the long run. Serious noise studies can lead to death.

6. Mechanical vibration: means mechanical vibration, which reaches the employee's body and might have undesirable repercussions. The intensity (meter/second) and frequency of vibration (vibration/Segundo) determine the vibration's amplitude. In general, mechanical vibrations are very disruptive for the body, both irregular in strength and frequency.

7. Smells: smells may be regarded as pollution surrounding the workplace since they can interfere with the focus of work, and constantly occurring odors could damage olfactory sensitivity. Air conditioning is one technique to avoid irritating smells around the office.

8. Fixing colors: The arrangement of colors at work should be as well studied and prepared as feasible. Indeed, the color pattern cannot be isolated from the decorative arrangements. It is understandable because color plays an essential role in feelings. The nature and effect of color sometimes cause joy, sadness, and others, as human sentiments can be stimulated in color.

Bagas Pradana Aulia; Imam Sucipto; Ahmad Gunawan. Influence of organizational culture, work discipline, and work environment on employee performance. 
9. Decoration: decoration is related to excellent coloring. Therefore, decorating is connected with the decoration of the workplace and how the layout, color layout, equipment, and others are arranged for work.

10. Music: according to experts, gentle music may inspire employees to work according to the mood, time, and location. Songs must thus be picked to perform at work. The attention of work will be impaired by unsuitable music listened to during work.

11. Security: To preserving the workplace and the working environment in a safe state, safety at work must be noted. The security factor must thus be acknowledged. One of the measures to preserve safety at work might benefit the staff of the security officer unit (SATPAM).

\section{Figure 1 Research Model}

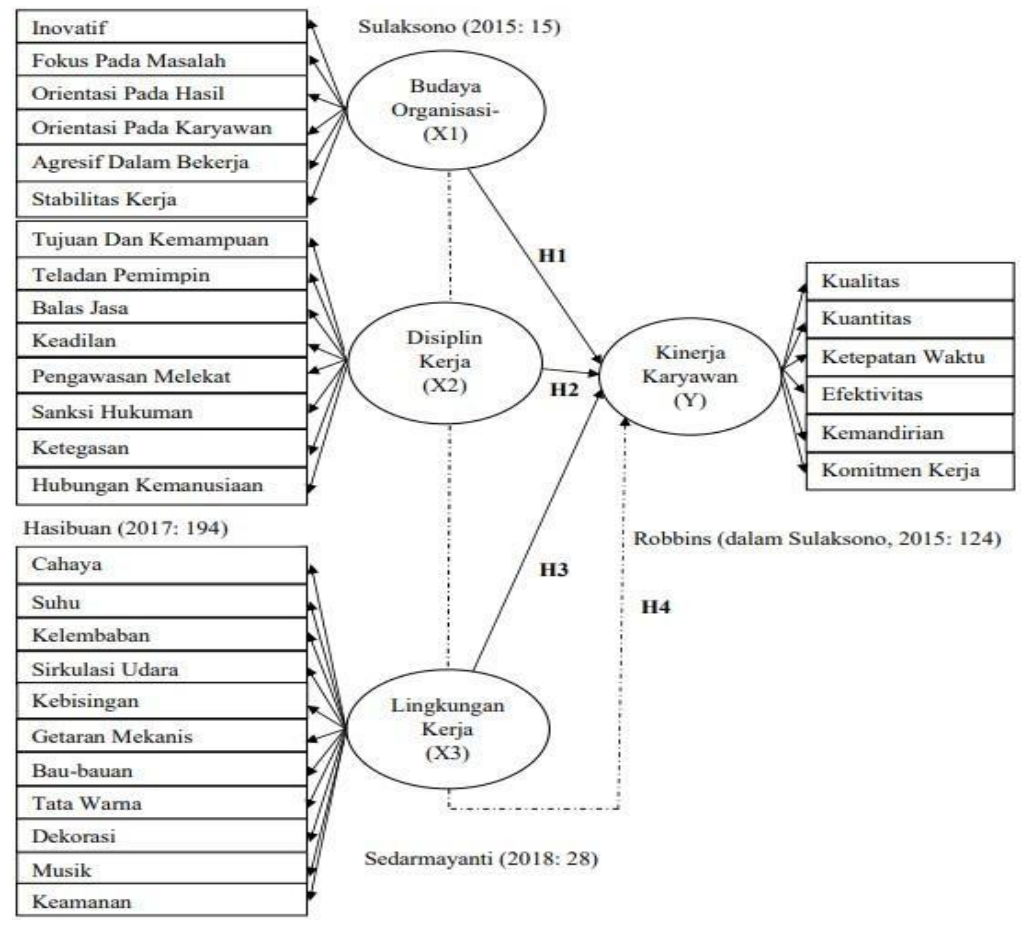

Referring to the research mentioned above methodology as well as the issue formulation outlined in the introduction, the following is the hypothesis for this study:

$\mathrm{H} 1$ (initial hypothesis):

The hypothesis is that organizational culture affects employee performance in the repack section of PT Mitsubishi Logistics Indonesia. This hypothesis is supported by Lailatus Safaah and Suparwati, who published an article titled "The Influence of Organizational Motivation and Culture on Employee Performance at PT KAI DAOP 8 Surabaya" in The Indonesian Business Journal, Vol. According to the findings of this study, organizational culture has a substantial impact on the performance of PT KAI DAOP 8 Surabaya personnel.

$\mathrm{H} 2$ (Second hypothesis): It is asserted that work discipline affects employee performance in PT Mitsubishi Logistics Indonesia's repack division, which is supported by Devi Komala Ayu and Jeffry H. Sinaulan in an article titled "The Effect of Incentives and Work Discipline on Employee Performance at PT Bintang Satu Does." According to the findings of this study, work discipline had a good and substantial influence on the performance of PT Bintang Satu Doea's EMPLOYEES.

H3 (ThirdHypothesis): It is stated that the work environment has an effect on employee performance in the repack section of PT Mitsubishi Logistics Indonesia, and Cynthia Novita Hidayat supports this hypothesis in an article titled "The Influence of the Work Environment and Work Motivation on Employee Performance at PT Keramik Diamond Industries'

Bagas Pradana Aulia; Imam Sucipto; Ahmad Gunawan. Influence of organizational culture, work discipline, and work environment on employee performance. 
Office." According to the findings of this study, the work environment had a favorable and substantial influence on the performance of PT Keramik Diamond Industries personnel.

H4 (Fourth supposition):

It is stated that organizational culture, work discipline, and work environment all affect employee performance in PT Mitsubishi Logistics Indonesia's repack division, which is supported by Anggy Henly Kumajas, Victor P. K. Lengkong, and Rudy S. Wenas in an article titled "Influence of Organizational Culture, Work Discipline, and Work Environment on Employee Performance." According to the findings of this study, organizational culture, work discipline, and work environment all had a favorable and substantial impact on the performance of employees at PT PLN (Persero) Suluttenggo Regional Office.

\section{METHODOLOGY}

This form of quantitative research is employed in this study. The authors employed an explanatory survey research design in their work, a strategy for explaining causal connections between two or more variables through hypothesis testing (Singarimbun and Effendi in the journal Meilinda et al., 2019).

The data for this study were derived from primary and secondary sources. The primary data for this study came from observations, interviews, and the distribution of questionnaires. Secondary data is gathered from a variety of sources. The survey sampled 74 workers. The sampling strategy used in this study is non-probability sampling with saturation sampling. As a result, the entire population was sampled in this study, namely the 74 employees of PT Mitsubishi Logistics Indonesia's repack division. The questionnaire employed in this case is a closed model because the author gave the response, and the assessment is based on the Likert scale, with each response receiving the following score: 5: Agree strongly, 4: Agree somewhat, 3: Neutral, 2: Disagree somewhat, and 1: Strongly disagree somewhat.

The data management method used in this study is calculated using the SPSS (Statistical Product and Service Solution) program version 25, a statistical computer program capable of managing statistical data quickly and precisely and transforming it into a variety of desired results for decision-making.

Data analysis is carried out quantitatively using descriptive or inferential statistics to determine whether the formulated hypothesis is true (Sugiyono, 2020: 17).

The validity and reliability of the data were determined in this study, as well as the classical assumption tests of normality, multicollinearity, heteroskedasticity, and linearity, as well as multiple linear regression hypothesis testing and data interpretation.

\section{RESEARCH AND DISCUSSION RESULTS}

According to the findings of the disseminated questionnaire, the following table depicts male and female employees:

Table 2 Respondents by Gender

\begin{tabular}{|c|c|c|}
\hline Gender & Frequency & Percentage \\
\hline Man & 21 & $28,4 \%$ \\
\hline Woman & 53 & $71,6 \%$ \\
\hline Total & 74 & $100 \%$ \\
\hline
\end{tabular}

Source: Processed questionnaire results

Employees of PT Mitsubishi Logistics Indonesia's repack division with a male gender ratio of 28.4 percent, and a female gender ratio of 71.6 percent can be identified from the table data. The following table summarizes the findings of the disseminated questionnaire on the number of workers by respondents' age group:

Table 3 Respondents by Age

\begin{tabular}{|c|c|c|}
\hline Age & Frequency & Percentage \\
\hline $18-23$ years & 29 & $39,2 \%$ \\
\hline
\end{tabular}

Bagas Pradana Aulia; Imam Sucipto; Ahmad Gunawan. Influence of organizational culture, work discipline, and work environment on employee performance. 


\begin{tabular}{|c|c|c|}
\hline $24-29$ years & 22 & $29,7 \%$ \\
\hline $30-35$ years & 14 & $18,9 \%$ \\
\hline Over 36 years & 9 & $12,2 \%$ \\
\hline Total & 74 & $100 \%$ \\
\hline
\end{tabular}

Source: Processed questionnaire results

Of the 74 participants investigated, the table shows findings of $39.2 \%$ or 29 respondents 18 to 23 years of age, $29.7 \%$ or 22 people 24 to 24 years of age, $18.9 \%$ or 14 people 30 to 35 years of age, and $12.2 \%$ or nine respondents 36 years of age. Based on the findings of the disseminated questionnaire, the following table shows the number of workers depending on education:

Table 4 Respondents by Education Level

\begin{tabular}{|l|l|l|}
\hline Level of Education & Frequency & Percentage \\
\hline SD equivalent & 2 & $2,7 \%$ \\
\hline Junior High School Equivalent & 15 & $20,3 \%$ \\
\hline High School Equivalent & 47 & $63,5 \%$ \\
\hline D3/S1 & 10 & $13,5 \%$ \\
\hline Total & 64 & $100 \%$ \\
\hline
\end{tabular}

Source: Processed questionnaire results

The chart indicated that of the 74 respondents who studied, $2.7 \%$ or two respondents were primary school students, $20.3 \%$ or 15 respondents had high school education equivalents, $63.5 \%$ or 47 were secondary school students evenly, while $13.5 \%$ or ten respondents were secondary school students. D3/S1. Depending on the findings of the disseminated questionnaire, in the following table, the number of employees based on the work-life of the respondent may be seen:

Table 5 Respondents by Working Life

\begin{tabular}{|l|l|l|}
\hline Working Time & Frequency & Percentage \\
\hline Less than one year & 16 & $21,6 \%$ \\
\hline $1-2$ years & 18 & $24,3 \%$ \\
\hline More than 2 years & 40 & $54,1 \%$ \\
\hline Total & 74 & $100 \%$ \\
\hline
\end{tabular}

Source: Processed questionnaire results

According to the table, 21.6 percent (16 respondents) had worked for less than a year, 24.3 percent (18 respondents) had worked for one to two years, and 54.1 percent (40 respondents) had worked for more than two years.

\section{Instrument Test}

\section{Validity Test}

A validity test is a valid or non-valid test of a statement to determine whether the statement in a questionnaire is accurate. A significant correlation between statements and the overall score of statements is indicated for valid statements. For the decision of whether or not a valid declaration is used, i.e., a 0.05 meaning test and a comparison using table $r$, a declaration is valid if it is considerably correlated to the total score of the declaration. Each statement is declared valid if the results show a significant value.

Table 6 Instrument Validity Test Results

\begin{tabular}{|l|l|l|l|l|}
\hline Variable & Statement & r count & $r$ table & Information \\
\hline \multirow{5}{*}{$\begin{array}{l}\text { Culture } \\
\text { Organization } \\
(X 1)\end{array}$} & 1 & 0,690 & 0,229 & Valid \\
\cline { 2 - 5 } & 2 & 0,794 & 0,229 & Valid \\
\cline { 2 - 5 } & 3 & 0,842 & 0,229 & Valid \\
\cline { 2 - 5 } & 4 & 0,812 & 0,229 & Valid \\
\cline { 2 - 5 } $\begin{array}{l}\text { Work Discipline } \\
\text { (X2) }\end{array}$ & 5 & 0,759 & 0,229 & Valid \\
\cline { 2 - 5 } & 6 & 0,736 & 0,229 & Valid \\
\cline { 2 - 5 } & 1 & 0,870 & 0,229 & Valid \\
\hline
\end{tabular}

Bagas Pradana Aulia; Imam Sucipto; Ahmad Gunawan. Influence of organizational culture, work discipline, and work environment on employee performance. 


\begin{tabular}{|c|c|c|c|c|}
\hline & 3 & 0,949 & 0,229 & Valid \\
\hline & 4 & 0,902 & 0,229 & Valid \\
\hline & 5 & 0,753 & 0,229 & Valid \\
\hline & 6 & 0,728 & 0,229 & Valid \\
\hline & 7 & 0,711 & 0,229 & Valid \\
\hline & 8 & 0,321 & 0,229 & Valid \\
\hline \multirow{11}{*}{$\begin{array}{l}\text { Work Environment } \\
\text { (X3) }\end{array}$} & 1 & 0,929 & 0,229 & Valid \\
\hline & 2 & 0,919 & 0,229 & Valid \\
\hline & 3 & 0,913 & 0,229 & Valid \\
\hline & 4 & 0,934 & 0,229 & Valid \\
\hline & 5 & 0,949 & 0,229 & Valid \\
\hline & 6 & 0,957 & 0,229 & Valid \\
\hline & 7 & 0,958 & 0,229 & Valid \\
\hline & 8 & 0,818 & 0,229 & Valid \\
\hline & 9 & 0,817 & 0,229 & Valid \\
\hline & 10 & 0,730 & 0,229 & Valid \\
\hline & 11 & 0,411 & 0,229 & Valid \\
\hline \multirow{6}{*}{$\begin{array}{l}\text { Employee Performance } \\
\text { (AND) }\end{array}$} & 1 & 0,710 & 0,229 & Valid \\
\hline & 2 & 0,726 & 0,229 & Valid \\
\hline & 3 & 0,738 & 0,229 & Valid \\
\hline & 4 & 0,818 & 0,229 & Valid \\
\hline & 5 & 0,798 & 0,229 & Valid \\
\hline & 6 & 0,768 & 0,229 & Valid \\
\hline
\end{tabular}

Source: SPSS processed data 25, 2021.

A $r$ value for the table $=0.229$ is obtained with $\mathrm{Df}=\mathrm{n}-2$ or $\mathrm{Df}=74-2=72$ and a meaning level of 0.05 . It is known that $r$ calculates greater than Table $r$ for all statement items, and the significance value is less than 0.05 . All declarations used to measure the variables of organizational culture (X1), work discipline (X2), work environment (X3), and employee performance $(\mathrm{Y})$ are therefore valid

\section{Reliability Test}

Reliability tests are used to determine the consistency of the measuring tool, i.e., whether it can be used, relied upon, and remain consistent when the gauge is repeated. The reliability test method used is Alpha from Cronbach. To determine whether or not certain limits like $>0.60$ are reliable. The Cronbach's Alpha coefficient results are shown in the following table to determine the research instruments' reliability.

Table 7 Instrument Reliability Testing Results

\begin{tabular}{|l|l|l|l|}
\hline Variable & $\begin{array}{l}\text { Cronbach' } \\
\text { s Alpha }\end{array}$ & $\begin{array}{l}\text { Test } \\
\text { Leve } \\
\text { I }\end{array}$ & Information \\
\hline Organizational Culture (X1) & 0,865 & 0,6 & Reliable \\
\hline Discipline of Work (X2) & 0,907 & 0,6 & Reliable \\
\hline Work Environment (X3) & 0,965 & 0,6 & Reliable \\
\hline Employee Performance (Y) & 0,853 & 0,6 & Reliable \\
\hline
\end{tabular}

Source: SPSS processed data 25, 2021.

Bagas Pradana Aulia; Imam Sucipto; Ahmad Gunawan. Influence of organizational culture, work discipline, and work environment on employee performance. 
The results of the reliability test are more remarkable than 0.60 for the Organizational Culture (0.865), Work Discipline (0.907), Work Environment (0.965), and Employee Performance (0.853), which means that they used instrument measuring is consistent and can be repeatedly used over time.

\section{Classic Assumption Test}

\section{Normality Test}

This normality test is used to determine whether or not the data population is normally distributed. The author used the One-Sample Kolmogorov Smirnovtest in this test. The data is declared normal distribution if the value exceeds 0.05 . The results of the Kolmogorov Smirnov Normality Test were obtained in this study

\section{Multicollinearity Test}

To test regression found a correlation between free variables. A good regression model should not occur correlations among free variables.

Essential decision-making based on tolerance values:

a. If tolerance $>0.10$, then there is no multicollinearity.

b. If tolerance $<0.10$, then multicollinearity occurs.

Essential decision-making based on VIF values:

a. If the VIF $<10.00$, then there is no multicollinearity.

b. If the VIF $>10.00$, then there is multicollinearity.

The value of organizational culture variables intolerance (X1) of 0.458 and the discipline variables (X2) of 0.568 and working environment variables (X3) of 0.626 were reported in this study. Because of the value of the three variables $>0.10$, there is no multicollinearity. Then for vif results, the value of the variable organizational culture (X1) from 2.184 is known, then the value of the variable working discipline (X2) from 1.760 and the value of a variable work environment $(X 3)$ from 1.597. Since the value of the three variables is $<10.00$, there is no multi-colinearity.

\section{Heteroskedasticity Test}

The heteroskedasticity test tests whether the variance inequality exists in regression models from residual observation to observation. A good regression model is that there is no heteroskedasticity.

The basis for this decision-making test is a. If $\mathrm{Sig}>0.05$. There is no heteroscedasticity. b. Heteroscedasticity occurs if $\mathrm{Sig}<0.05$. Based on the findings of this study, the meaning of the variable for the organizational culture $(x 1)$ is 0.956 , then the meaning of the working discipline variable $(x 2)$ is 0.701 , and the meaning of the working environment variable $(\times 3)$ is 0.304 . The value of the three variables above 0.05 can be concluded that Heteroscedasticity is not present in the three variables.

\section{Linearity Test}

The linearity test is necessary to determine the linear connection between a free and a bound variable. Whether or not the meaning value in the deviation from linearity $>$ 0.05 is said to be linear is the basis for deciding the normal distribution-variable of the

Bagas Pradana Aulia; Imam Sucipto; Ahmad Gunawan. Influence of organizational culture, work discipline, and work environment on employee performance. 
organization's culture $(\mathrm{X} 1)$ with variable employee performance $(\mathrm{Y})$. Based on the results of the linearity test, the variability of the linearity of the Organizational Culture Variable (X1) of 0.058 and the result of the deviation of the linearity of $>0.05$ may be concluded that each free variable has a relation and the bound variable is linear. Variable Work Discipline (X2) with variable Employee Performance $(Y)$. Based on the results of the linearity test for the deviation from the linearity variable (X2) value of 0.473 and the result of a deviation from the linearity $>05$, the relationship between each free variable and the bound variable can be concluded that it is linear. Employee Performance Variable Work Environment Variable (X3) (Y). Based on the results of the linearity test for the deviation of the linearity of the operating environment variable of 0.500 and the result of a linearity deviation $>0.05$, the relationship between each free variable can be concluded with a linear bound variable.

\section{Multiple Linear Regression Test}

Table 8 Multiple Linear Regression Test Results

\begin{tabular}{|c|c|c|c|c|c|}
\hline \multicolumn{6}{|c|}{ Coefficients } \\
\hline \multirow[b]{2}{*}{ Model } & \multicolumn{2}{|c|}{ Unstandardized Coefficients } & \multirow{2}{*}{$\begin{array}{l}\text { Standardized Coefficients } \\
\text { Beta }\end{array}$} & \multirow[b]{2}{*}{$\mathrm{T}$} & \multirow[b]{2}{*}{ Sig. } \\
\hline & B & Std. Error & & & \\
\hline \begin{tabular}{l|l}
1 & (Constant)
\end{tabular} & 8.400 & 2.009 & & 4.180 & .000 \\
\hline Organizational Culture & .420 & .107 & .428 & 3.941 & .000 \\
\hline Work Discipline & .138 & .049 & 273 & 2.802 & .007 \\
\hline Work Environment & .052 & .023 & 215 & 2.314 & .024 \\
\hline
\end{tabular}

Source: SPSS processed data version 25, 2021.

The linear regression equation between the organic culture variable (X1), Work Discipline variable (X2) and Work Environment Variable (X3) is: Based on the regression output, the linear regression equation is:

$\mathrm{Y}=\mathrm{a}+\mathrm{b} 1(\mathrm{X} 1)+\mathrm{b} 2(\mathrm{X} 2)+\mathrm{b} 3(\mathrm{X} 3)+\mathrm{e}$

$Y=8,400+0,420(X 1)+0,138(X 2)+0,052(X 3)+39,4 \%$

1. The constant value of 8.400 is not interpreted as the smallest number on the scale of the Likert is one. There is no zero on the Likert scale.

2. The 0.420 regression coefficient of the organizational culture means that if the corporate culture is improved, the performance of employees improves with continuous work discipline and work environment

3. The 0.138 regression of discipline means that if work discipline is improved, the performance of employees will improve if the organizational culture and the working environment are taken into account

4. The regression coefficient of 0.052 in the working environment means that if the working environment is improved, the performance of employees will improve, with a constant organizational and labor discipline.

\section{Hypothesis Test}

\section{Test $\mathbf{t}$ (Partial)}

The t-test is designed to determine how much an independent variable $(X)$ influences a dependent variable $(\mathrm{Y})$ if the other variable is constant. The tests were carried out in two directions, and significant tests of the influence of individually independent variable relationships on dependent variables were conducted. The decision to take this test $t$ is:

Bagas Pradana Aulia; Imam Sucipto; Ahmad Gunawan. Influence of organizational culture, work discipline, and work environment on employee performance. 
1. If the value of meaning $<0.05$ or $t$ calculates $>t$ in the table, then variable $X$ affects variable $\mathrm{Y}$.

2. If the value $>0.05$ or $t$ calculates $<t$ of a table, no effect of variable $X$ exists on variable Y.

Formula: $\mathrm{t}$ table $=\mathrm{t}(\mathrm{a} / 2 \mathrm{:} \mathrm{n}-\mathrm{k}-1)=74-3-1=70=\mathrm{t}(0.025: 70)=1,994$

Table 8 shows multiple linear regression tests that can calculate organizational cultures $(X 1)$ above the $t$ table value $(3.941>1.994)$ or the meaning value obtained by 0.00 $<0.05$. It can then be concluded that the performance of employees partially affects the organizational culture $(\mathrm{X} 1)(\mathrm{Y})$. The results of this study support the results of previous research carried out at PT KAI DAOP 8 Surabaya in The Indonesian Business Journal, Volume 11 No 22020 by Lailatus Safaah and Suparwati in an article entitled The Impact of Motivation and Organizational Culture on Employee Performance. The results of this study show that corporate culture has an important impact on employee performance Table 8 of the double linear regression test also reveals that the working discipline variables (X2) are calculated to be higher than the value of the $t(2,802>1,994)$ or the significance of $0.007<0.05$. The conclusion can then be drawn that work discipline (X2) partially affects the performance of employees $(\mathrm{Y})$. The study results support the results of earlier research by Devi Komala Ayu and Jeffry H. Sinaulan in the 2018 Journal of Economics vol. 20, no. 5 , on the impact of incentives and work discipline on employee performance at PT Bintang Satu Dua. The results of this research show that the field of work has a positive and significant impact on the performance of employees. The last known in Table 8 of the double linear regression test then showed that the unstable work environment (X3) is calculated to be more than $t(2,314>1,994)$ or $0,024<0,05$. The conclusion is that the working environment $(\mathrm{X} 3)$ partially influences employee performance $(\mathrm{Y})$.

The results of this study support the results of previous research conducted by Cynthia Novita Hidayat in an article in the journal AGORA Vol. 3, No. 22015 entitled The Impact of Work Environment and Working Motivation on Employee Performance by PT Keramik Diamond Industries Office. The results of this study show that the working environment has a positive and significant effect on the performance of employees.

$\mathrm{F}$ test Test (Simultaneous) The $\mathrm{F}$ test is essential to determine whether all independent or free variables in the model have a common influence on dependent variables. The decision of this $\mathrm{F}$ test is as follows:

1. If the meaning value $<0.05$ or $F$ calculates $>F$ for the table, then variable $X$ simultaneously affects variable $\mathrm{Y}$.

2. When the value of significance $>0,05$ is $<F$ of the table, the simultaneous effect of variable $X$ on variable $Y$ is not present.

Formula:

DF $1=$ DF 1 (Number of variables -1 ) $4-1=34-1$

DF $2=($ Number of interviewers - number of variables free of charge -1$) 74-3-1=70 \mathrm{~F}=$ 2,736 74-3-1

Results of Table $9 \mathrm{~F}$ ANOVA

ANOVA

Bagas Pradana Aulia; Imam Sucipto; Ahmad Gunawan. Influence of organizational culture, work discipline, and work environment on employee performance. 


\begin{tabular}{|c|c|c|c|c|c|}
\hline Model & Sum of Squares & Df & Mean Square & $\mathrm{F}$ & Sig. \\
\hline 1 Regression & 236.738 & 3 & 78.913 & \begin{tabular}{|l|}
38.38 \\
0
\end{tabular} & $.000^{\mathrm{b}}$ \\
\hline Residual & 143.924 & 70 & 2.056 & & \\
\hline Total & 380.662 & 73 & & & \\
\hline \multicolumn{6}{|c|}{$\begin{array}{l}\text { a. Dependent Variable: Employee Performance } \\
\text { b. Predictors: (Constant), Work } \\
\text { Environment, Work Discipline, } \\
\text { Organizational Culture } \\
\text { Source. SPSS nocessed data version } 252021\end{array}$} \\
\hline
\end{tabular}

Based on the output of the table 9 , it is known that the value of $F$ calculates 38,380 $>2,736 \mathrm{~F}$ table and the significance value of $0.00<0.05$. So it can be concluded that Organizational Culture, Work Discipline, and work environment simultaneously affect employee performance.

The results of this study support the results of previous research conducted by Anggy Henly Kumajas, Victor P. K. Lengkong, and Rudy S. Wenas in an article entitled Influence of Organizational Culture, Work Discipline, and Work Environment on Employee Performance at PT PLN (Persero) Suluttenggo Regional Office published in the journal EMBA, Vol. 4, No.4, 2016. The results of this study stated that the organizational culture, work discipline, and work environment together had a positive and significant effect on the performance of employees of PT PLN (Persero) Suluttenggo Regional Office.

\section{Determination Coefficient Test}

Table 10 Results of the Coefficient of Determination Test

\begin{tabular}{|c|c|c|c|c|}
\hline \multicolumn{5}{|c|}{ Model Summary } \\
\hline $\begin{array}{l}\text { Mod } \\
\text { el }\end{array}$ & $\mathrm{R}$ & $\begin{array}{l}\mathrm{R} \\
\text { Square }\end{array}$ & \begin{tabular}{|l|} 
Adjusted \\
R Square
\end{tabular} & $\begin{array}{l}\text { Std. Error of } \\
\text { the Estimate }\end{array}$ \\
\hline 1 & $\begin{array}{l}.789 \\
a\end{array}$ & .622 & .606 & 1.43390 \\
\hline \multicolumn{5}{|c|}{$\begin{array}{l}\text { a. Predictors: (Constant), Work Environment, } \\
\text { Work Discipline, Organizational Culture } \\
\text { Source: SPSS processed data version } 25 \\
\end{array}$} \\
\hline
\end{tabular}

Based on the output of the table above, the coefficient of determination (Adjusted $\mathrm{R}$ Square) is known to be 0.606 . The magnitude of the coefficient of determination is equal to $60.6 \%$, and the figure means that Organizational Culture, Work Discipline, and the Work Environment affect Employee Performance by $60.6 \%$. While the rest $(100 \%-60.6 \%=$ $39.4 \%$ ). $39.4 \%$ were affected by other variables outside of this regression model.

An $\mathrm{R}$ grade indicates the strength of an Organizational Culture (X1), Work Discipline (X2), and Work Environment (X3) relationship strength with Employee Performance $(Y)$. The figure of 0.606 or $60.6 \%$ indicates a strong relationship.

\section{Discussion}

1. Influence of organizational culture on employee performance

The results of the first hypothesis testing on the influence of organizational culture on employee performance found that there was a positive and significant influence on employee performance based on a calculated $t$ value more significant than the table's $t$ value $(3,941>1,994)$ or with a level of significance of the result of 0.00 that value was less than 0.05 . By looking at the hypothesis test, it can be concluded that organizational culture is one of the factors that affect employee performance.

Bagas Pradana Aulia; Imam Sucipto; Ahmad Gunawan. Influence of organizational culture, work discipline, and work environment on employee performance. 
A managed organizational culture as a management tool will influence and stimulate employees to behave positively, dedicatedly, and productively. Cultural norms are invisible but are forces that stimulate behavior to produce performance effectiveness. Organizational culture is a state of invisible social power but can influence employees to perform work activities (Sutrisno in the journal Jurman, 2014).

2. The effect of work discipline on employee performance

The results of the second hypothesis of the effect of work discipline on employee performance found that there was an effect of work discipline on employee performance based on the value of $t$ calculated greater than the value of $t$ table $(2,802>1.994)$ or with a level of significance of the result of 0.007 the value is less than 0.05 . By looking at the hypothesis test, it can be concluded that work discipline is one factor affecting employee performance.

Work discipline is always expected to be the nature of every human resource in the company because, with discipline, the company will continue to run well and be able to achieve its goals well. Work discipline is essential and the key to achieving good performance, and in the absence of work discipline is challenging to achieve company goals (Sedarmayanti in the journal Supeno et al., 2017).

3. The impact of the work environment on employee performance

The third hypothesis of the effect of the work environment on employee performance found that there was an effect on the work environment on employee performance based on a calculated value more significant than the t table value $(2,314>1,994)$ or with a level of significance of the result of 0.024 the value was less than 0.05 . By looking at the hypothesis test, it can be concluded that the work environment is one of the factors that affect employee performance.

The work environment is a situation around the workplace that can have good and bad effects on employee performance and affect the employee itself. Comfortable working environment conditions can support the design of an efficient work system so that the company's goals are achieved. Directly or indirectly, the work environment will impact employees' physical and spiritual health, affecting their performance (Wursanto in nabawi journal, 2019).

4. Influence of organizational culture, work discipline, and work environment on employee performance

The results of the fourth hypothesis test showed that organizational culture, work discipline, and work environment influenced employee performance and can be a good predictor of employee performance based on a calculated value greater than $f$ table $(38,380>2,736)$ or with a level of significance of the result of 0.00 that value is less than 0.05 .

The results of this hypothesis mean that the relationship between the three independent variables, namely organizational culture, work discipline, and work environment, to variable dependents, i.e., employee performance has an influence simultaneously and indicates this model can be used in predicting employee performance which means if the company applies an excellent organizational culture between fellow employees or between employees and superiors. The company's work discipline that is carried out firmly for its employees and the company provides and facilitates a comfortable work environment will improve employee performance.

\section{CONCLUSION AND RECOMMENDATION}

\section{Conclusions}

1. An organizational culture consisting of six indicators, namely innovative, focused on problems, orientation on results, orientation in employees, aggressive work, and work stability, positively affect employee performance.

2. Work Discipline consists of eight indicators, namely goals and abilities, an example of leaders, reciprocity, justice, inherent supervision (waskat), punitive sanctions, assertiveness, and humanitarian relations positively affect employee performance.

3. The work environment consists of eleven indicators: light, temperature, humidity, air circulation, noise, mechanical vibrations, odors, color order, decoration, music, and safety, which positively affect employee performance.

Bagas Pradana Aulia; Imam Sucipto; Ahmad Gunawan. Influence of organizational culture, work discipline, and work environment on employee performance. 
4. Then after the value of $t$ was calculated, the research continued to find out the test value $\mathrm{F}$ knew value $\mathrm{F}$ calculated greater than $\mathrm{F}$ table and significance value of $0.00<0.05$. So that simultaneously organizational culture, work discipline, and work environment positively affect employee performance.

\section{Suggestion}

1. The company should socialize and strengthen its organizational culture, especially in employee behavior in carrying out their work, and there are still many employees who are less concerned about their behavior towards the rules that upon have been agreed.

2. In addition to strengthening the organizational culture, the company must also pay more attention to why employees still take undisciplined actions against their work. It is seen from the observations and interviews conducted by the author to employees and superiors that there are still many employees who take undisciplined actions because some of the main things are inappropriate compensation and a sense of injustice that is felt between the employees of the repack section and the core employees of PT Mitsubishi Logistics Indonesia.

3. After paying attention to organizational culture and work discipline, the company should also work comfortably. The results of observations obtained by the author, there are still some things that must be considered, such as limited use of air conditioners, poor air circulation, and odors that are very felt from various products in storage. These things affect employee comfort when working.

4. PT Mitsubishi Logistics Indonesia, as a company engaged in warehousing of food, beverages, medical devices, and other goods for temporary storage and repackaging manufacturing for other companies, is obliged to improve the performance of its employees. It can be achieved if the employees can be known factors to improve their performance. Based on the above three things, organizational culture, work discipline, and work environment are essential factors in improving employee performance at PT Mitsubishi Logistics Indonesia, especially repack employees.

\section{BIBLIOGRAPHY}

Ayu, D. K \& Sinaulan, J. H. (2018). Influence Insentif dan Disiplin Kerja Terhadap Kinerja Karyawan PtherePT Bintang Satoe Doea. Journal of Economics Vol. 20(3), 373-382.

Beverly Tamara Lampoliuw, Bernhard Tewal, and Mac Donald Walangitan in an article entitled "Influence of Organizational Culture, Work Discipline, and Work Environment on Performance at Bank BRI Manado Branch Office" Influence of Organizational Culture in the journal EMBA, Vol. 9, No. 1, 2021. The results of this study state that organizational culture, work discipline, and work environment together affect employee performance.

Hasibuan, Malayu, S. P. (2017). Revised Edition of Human Resource Management. Jakarta: Bumi Aksara.

Hidayat, C. N. (2015). The Influence of The Work Environment and Work Motivation on the Performance of Employees of THE Office of PT Keramik Diamond Industries. Journal AGORA Vol. 3(2), 78-83.

Kumajas, A. H., Lengkong, V. P \&R udy S. Wenas, R. S. (2017). Influence of Budaya Organisasi, Disiplin Kerja, and Lingkungan Kerja Terhadap Kinerja. Jurnal EMBA Vol.4(4),1200-1208.

Bagas Pradana Aulia; Imam Sucipto; Ahmad Gunawan. Influence of organizational culture, work discipline, and work environment on employee performance. 
The Management Journal of BINANIAGA Vol. 06, No.02, December 2021

p-ISSN: 2527 - 4317, e-ISSN: $2580-149 x$

$6^{\text {th }}$ Accreditation Rating: April 04, $2019-$ April 03, 2024

Mangkunegara, A. A. A. P. (2017). Management of Human Resources of the Company. Bandung: Teenager Rosdakarya.

Meilinda, H., Budianto, A \& Kader, M. A. (2019). Effect of Remuneration and Work Culture on Employee Performance (A Study at the Citanduy Banjar River Region). Business Management and Entrepreneurship Journal Vol. 1(3), 141-154.

Muis, M. R., Jufrizen, J \& Fahmi, M. (2018). Influence Budaya Organisasi and Komitmen Organisasi Terhadap Kinerja Karyawan. Jesya (Journal of Islamic Economics and Economics) Vol. 1(1). 9-25.

Safaah, L. \& Suparwati, S. (2020). Pengaruh Motivation and Budaya Organisasi Terhadap Kinerja Karyawan PtherePT KAI DAOP 8 SURABAYA. Indonesian Business Journal Vol. 11(02),120-137.

Setyaningrum, R. P., Bintarti, S \& Esthi, R.B. (2019). Human Resource Management. Bekasi: Media Discourse Partners.

Sedarmayanti. (2018). Work Order and Work Productivity. Bandung: Mandar Maju.

Sucipto, I., \& Gunawan, A. (2021). Role of Work Discipline and Work Environment in Employee Performance of Molding Department of PT FCC Indonesia. Journal of Management and Accounting Vol. 16(2), 18-29.

Sugiyono. (2020). Quantitative, Qualitative, and R\&D Research Methods. Bandung: Alfabeta.

Sulaksono, Hari. (2015). Organizational Culture and Performance. Yogyakarta: CV Budi Utama.

Wardani, R. K., M. Mukzam, M. D \& Mayowan, Y. (2016). Influence of Organizational Culture on Employee Performance (Study on Employees of PT Karya Indah Buana Surabaya). Journal of Business Administration Vol. 31(1), 58-65.

Bagas Pradana Aulia; Imam Sucipto; Ahmad Gunawan. Influence of organizational culture, work discipline, and work environment on employee performance. 